\title{
Synthesis and functional properties of mixed titanium and cobalt oxides
}

\author{
M.V.Ved', N.D.Sakhnenko, A.V.Karakurkchi, \\ M.V.Mayba, A.V.Galak \\ National Technical University "Kharkiv Polytechnic Institute",
2 Kyrpychova St., 61002 Kharkiv, Ukraine
}

Received March 24, 2017

\begin{abstract}
Peculiarities of plasma-electrolytic oxidation of the aluminum alloys in diphosphate electrolytes are discussed. It is shown that PEO parameters depend on the composition and concentration of the components of the working solutions. The mechanism of cobalt oxides incorporation into the composition of surface layers is proposed. It has been established that the oxidation of titanium in citrate-diphosphate electrolytes promotes the formation of mixed oxide layers $\mathrm{TiO}_{x} \cdot \mathrm{CoO}_{y}$. The obtained mixed oxide systems have a developed microporous globular-toroidal surface and are characterized by a complex of enhanced functional properties - corrosion and abrasion resistance, catalytic activity in the carbon (II) oxide conversion reaction.
\end{abstract}

Keywords: titanium alloy, plasma electrolytic oxidation, titania, cobalt oxides, mixed oxides, corrosion resistance, catalytic activity, abrasion resistance.

Рассмотрены особенности плазменно-электролитического оксидирования сплавов титана в щелочных билигадных электролитах. Показано, что параметры ПЭО зависят от состава и концентрации компонентов рабочих растворов. Предложен механизм инкорпорации оксидов кобальта в состав поверхностных слоев. Установлено, что оксидирование титана в цитратно-дифосфатных электролитах способствует формированию смешанных оксидных слоев $\mathrm{TiO}_{x} \cdot \mathrm{CoO}_{y}$. Полученные смешанные оксидные системы имеют развитую микропористую глобулярно-торообразную поверхность и характеризуются комплексом повышенных функциональных свойств - коррозионной стойкостью, стойкостью к абразивному износу, каталитической активностью в реакции конверсии оксида углерода( II).

Синтез та функціональні властивості змішаних оксидів титану та кобальту. М.В.Ведь, М.Д.Сахненко, Г.В.Каракуркчі, М.В.Майба, О.В.Галак.

Розглянуто особливості плазмово-електролітичного оксидування сплавів титану в лужних білігадних електролітах. Показано, що параметри ПЕО залежать від складу і концентрації компонентів робочих розчинів. Запропоновано механізм інкорпорації оксидів кобальту до складу поверхневих шарів. Встановлено, що оксидування титану у цитратно-дифосфатних електролітах сприяє формуванню змішаних оксидних шарів $\mathrm{TiO}_{x} \cdot \mathrm{CoO}_{y}$. Отримані змішані оксидні системи мають розвинену мікропористу глобулярно-торообразну поверхню і характеризуються комплексом підвищених функціональних властивостей - корозійною стійкістю, стійкістю до абразивного зношування, каталітичною активністю в реакції конверсії оксиду карбону (II).

\section{Introduction}

Many unique properties of titanium and titanium-based alloys specify the demand for it and its broad application by the medi- cine, utility companies and other branches of the industrial sector. In comparison with other structural materials titanium has two main advantages, in particular high specific strength and corrosion resistance even in 
the harsh environment and when in contact with many aggressive chemical reagents [1]. Other properties of titanium, for example non-magneticity, high melting temperature, low coefficient of thermal expansion, etc. are of great importance for other application fields [2-4]. Its biological inertness in the human body, high mechanical and anticorrosion properties specify its wide application for the medicine. Titanium and its alloys are characterized by a high resistance to the fatigue wear at alternate loads, which is rather important for the manufacture of intraosteal locks, internal and external prosthetic devices [5-7].

At the present time, many techniques and methods are available that are used for the formation of functional coatings at titanium alloys that enable the expansion of the spectrum of physical and mechanical properties of the materials and the field of their application [8,9]. Electrochemical technique for the synthesis of oxide layers is one of the most practically feasible and economically efficient methods because it enables the production of coatings uniform in thickness and composition with high adhesive properties [10-13].

As of today, an ample amount of methods are available that are used for the formation of functional coatings doped with different components, in particular transition metal oxides. However most of them are characterized by high labor-intensiveness and multistage process $[14,15]$. Providing a uniform sediment distribution and sufficient adhesion presents a considerable problem. The method of plasma-electrolytic oxidation enables the formation of oxide matrix-substrate and the filling of it with the transition metal oxide within one stage, and as a result, a high dopant content is obtained, which is uniform in thickness and composition, and a high adhesive strength is also achieved [16].

Titanium like other valve metals is subjected to the oxidation to obtain coatings of a different purpose, for example these can be used as catalytically active layers, corrosion resistant and antifriction coatings, etc. The guided synthesis of the films of a prescribed composition and structure is required to create efficient protective coatings and new materials. The coatings formed in the microplasma mode are characterized by the biological inertness, X-ray transparent, corrosion resistance and the developed globular structure. It is known that metal oxides are used as catalysts for many technological processes in gas and liquid media, and as electrode materials for electro-synthesis and chemical current sources, etc. [17]. The oxides of nonstoichiometric composition are of special interest, because the rate of electrochemical and chemical processes is increased with an increase in a degree of deviation from the stoichiometry [18]. In this connection it is worth to note that the method of plasmaelectrolytic oxidation (PEO) allows us to improve physical and chemical properties of the items, create universal polyfunctional tissue-compatible composite materials, imparting appropriate properties to them, in particular anticorrosion, tribological and bioinert properties and get the contact surface of implanted structures of a wanted structure and thickness [19-21].

Developing new approaches to the formation of surface structures on the metals and alloys that contain the specified ratio of the compounds of bivalent, trivalent and polyvalent metals, including precious metals is of great interest for the creation of new functional materials used for the catalysis, for example for the processes that require high heat conductivity [22]. In this connection, the doping of titanium oxides with cobalt is considered to be the most promising approach to the synthesis of catalytic and biocompatible materials [23].

Peculiarities of the PEO synthesis of mixed oxide coatings $\mathrm{TiO}_{x} \cdot \mathrm{CoO}_{y}$ and their functional properties are considered in this article.

\section{Experimental}

The composition of studing titanium VT1-0 alloy was, wt. $\%: \mathrm{Ti}-99.2-99.7$, $\mathrm{Fe}<0.25, \mathrm{C}<0.07, \mathrm{Si}<0.1, \mathrm{~N}<0.04, \mathrm{O}<0.2$, and impurities -0.3 . The pre-treatment of the samples included mechanical cleaning from the process contaminants, degreasing in a $0.2-0.3 \mathrm{M} \mathrm{NaOH}$, etching in a mixture of a 0.1-0.3 M HF and 0.3-0.9 $\mathrm{MHNO}_{3}$, and rinsing with distilled water.

Coatings were formed in an electrolyte composition, mol. $\mathrm{dm}^{-3}: \quad 0.3 \quad \mathrm{~K}_{4} \mathrm{P}_{2} \mathrm{O}_{7}, \quad 0.1$ $\mathrm{Na}_{3} \mathrm{C}_{6} \mathrm{H}_{5} \mathrm{O}_{7}, 0.1 \mathrm{CoSO}_{4}$.

The PEO of VT1-0 alloy was conducted using a B5-50 stabilized power supply that maintained voltage up to $300 \mathrm{~V}$. PEO was implemented in an electrolytic cell under conditions of forced cooling of the electrolyte to a temperature of $25-30^{\circ} \mathrm{C}$ and stirring the electrolyte. A current density varied in a range of $1-5 \mathrm{~A} \cdot \mathrm{dm}^{-2}$, the processing time was 30 to $60 \mathrm{~min}$. 

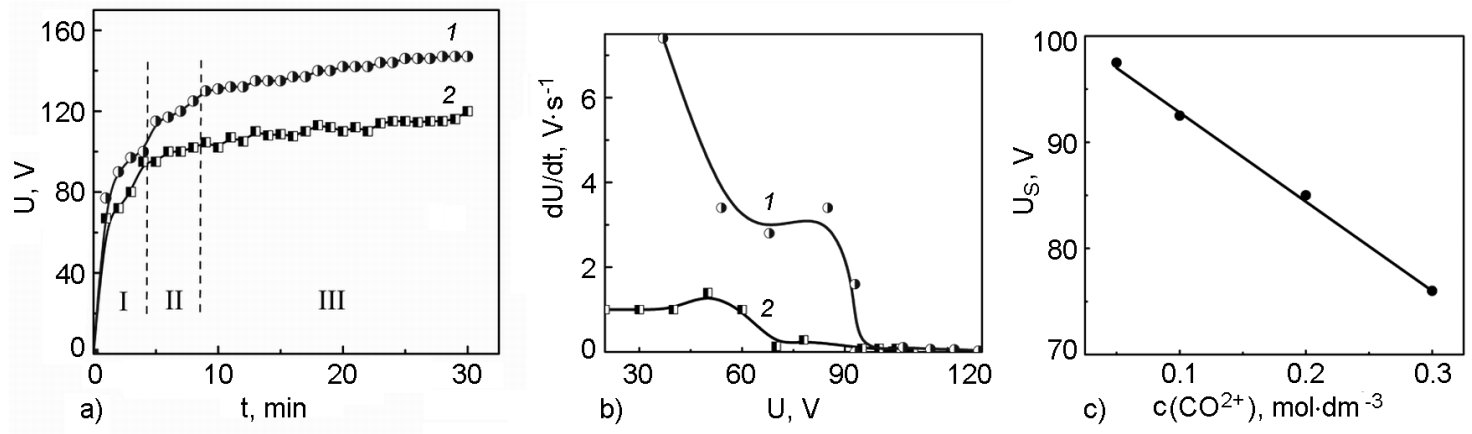

Fig. 1. Chronograms of the voltage $U$ (a), rates of voltage change $d U / d t$ (b) and spark voltage $U_{s}$ dependences on the cobalt sulfate concentration (c). Electrolyte composition, $\mathrm{mol} \cdot \mathrm{dm}^{-3}: 1-0.3$ $\mathrm{K}_{4} \mathrm{P}_{2} \mathrm{O}_{7}, 0.1 \mathrm{Na}_{3} \mathrm{C}_{6} \mathrm{H}_{5} \mathrm{O}_{7}, 0.1 \mathrm{CoSO}_{4} ; 2-0.3 \mathrm{~K}_{4} \mathrm{P}_{2} \mathrm{O}_{7}$.

The chemical composition of the coatings was determined by X-ray photoelectron spectroscopy on an INCA Energy 350 energy dispersive spectrometer; X-ray radiation was excited via exposing the samples to a $15 \mathrm{keV}$ electron beam. In addition, X-ray fluorescence analysis was conducted using a SPRUT portable spectrometer with a relative standard deviation of $10^{-3}-10^{-2}$; the error in determining the component content was \pm 1 wt. $\%$. The surface morphology of the coatings was studied using a Zeiss EVO 40XVP scanning electron microscope (SEM). Images were recorded by the registration of secondary electrons (BSEs) via scanning with an electron beam; this mode made it possible to study the topography with a high resolution and contrast ratio.

The structure of the deposits was examined by X-ray diffraction analysis using a diffractometer (DRON-2.0) in the emission of iron anode and $\mathrm{CuK} \alpha$ radiation.

The corrosion behavior of titanium samples with oxide coatings in aggressive test medium $0.1 \mathrm{M} \mathrm{NaCl}$ was studied by impedance spectroscopy technique [24]. Measurements were performed using automatic alternating current bridge R-5083 over the serial equivalent circuit in frequency range $20-1 \cdot 10^{5} \mathrm{~Hz}$. Auxiliary electrodes - coplanar plates of corrosion-resistant steel X18H10T. Potentiometric measurements in media $2 \mathrm{M} \mathrm{NaOH}$ and Ringer's (composition, mol. $\mathrm{dm}^{-3}: \mathrm{NaCl}-$ $\left.0.15, \mathrm{KCl}-0.004, \mathrm{CaCl}_{2}-0.004\right)$ solutions were used to verify the results.

The abrasion rate for the materials $\Delta l / \Delta t$ was determined by the Calotte method on the calotester [25].
The catalytic properties of the oxide systems were studied in the model reaction oxidation of carbon (II) oxide to carbon (IV) oxide as in [26].

\section{Results and discussion}

Chronograms of the voltage of mixed oxide coatings (Fig. 1a) have a classic shape with three typical sections. In the pre-spark region (section I) $U(t)$ dependences obtained in diphosphate electrolyte (Fig. 1a, curve 1) are actually linear due to the formation in first 2-3 min of the barrier titanium oxide with the current efficiency close to $100 \%$. In the electrolytes that contain $\mathrm{Co}(\mathrm{II})$, the voltage at section I is higher (Fig. 1a, curve 2), consequently $\mathrm{Co}(\mathrm{II})$ oxidation and formation of mixed $\mathrm{TiO}_{2} \cdot \mathrm{CO}_{3} \mathrm{O}_{4}$ oxides occur already in the pre-spark region. It should be noted that the cobalt oxidation (II) can progress by the following routes:

$$
\begin{gathered}
3 \mathrm{Co}(\mathrm{OH})_{2}+2 \mathrm{OH}^{-}=\mathrm{Co}_{3} \mathrm{O}_{4}+4 \mathrm{H}_{2} \mathrm{O}+2 e, \\
2 \mathrm{Co}(\mathrm{OH})_{2}+2 \mathrm{OH}^{-}=\mathrm{Co}_{2} \mathrm{O}_{3}+3 \mathrm{H}_{2} \mathrm{O}+2 e, \\
\mathrm{Co}(\mathrm{OH})_{2}+2 \mathrm{OH}^{-}=\mathrm{CoO}_{2}+2 \mathrm{H}_{2} \mathrm{O}+2 e, \\
2 \mathrm{Co}_{3} \mathrm{O}_{4}+\mathrm{H}_{2} \mathrm{O}=3 \mathrm{Co}_{2} \mathrm{O}_{3}+2 \mathrm{H}^{+}+2 e, \\
\mathrm{Co}_{2} \mathrm{O}_{3}+\mathrm{H}_{2} \mathrm{O}=2 \mathrm{CoO}_{2}+2 \mathrm{H}^{+}+2 e
\end{gathered}
$$

The reactions (1-5) result in the formation of insufficiently stable mixed cobalt oxide (II, III) that crystallizes in the spinel lattice with the specific resistance of (1.051.6) $10^{4} \Omega \cdot \mathrm{cm}$. The CoO oxide with higher specific electric resistance $10^{6}-10^{10} \Omega \cdot \mathrm{cm}$ is formed in the discharge channel at temperatures above $1230 \mathrm{~K}$ by the reaction: 
a)

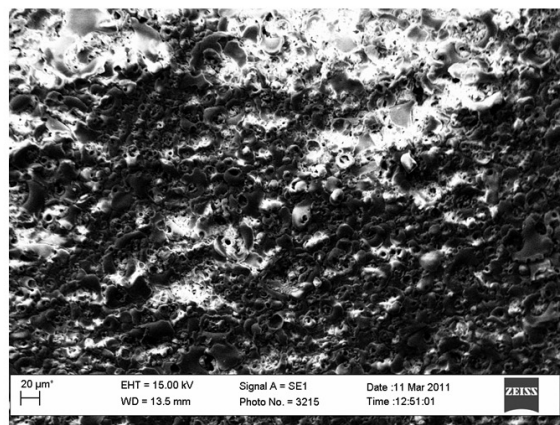

c)

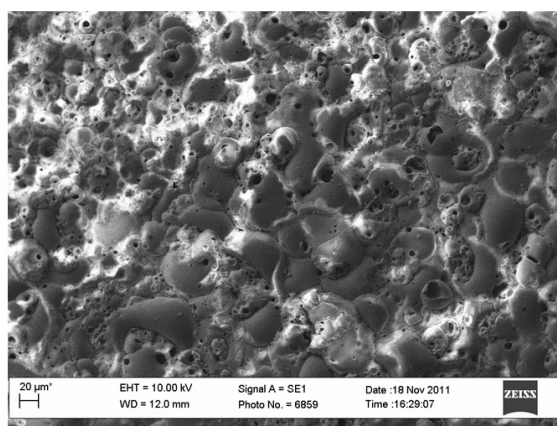

b)

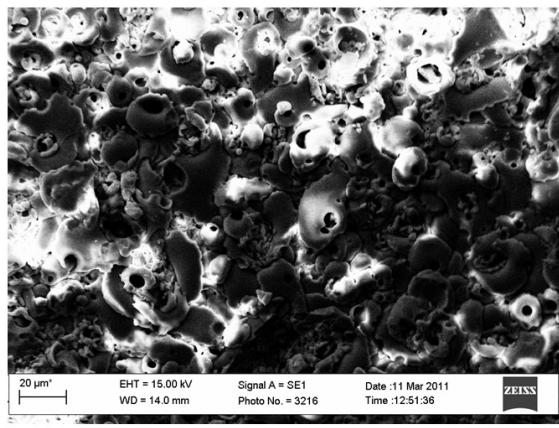

d)

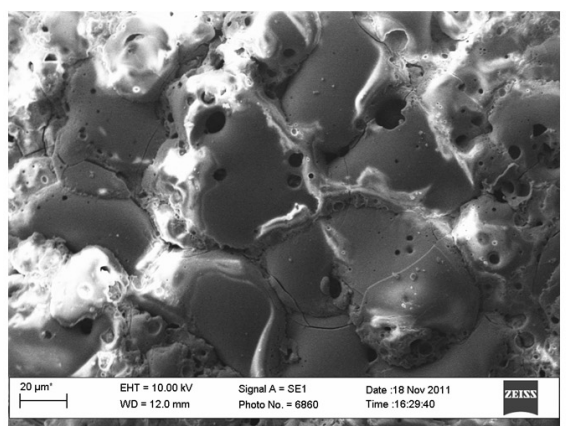

Fig. 2. Micrographs of the surface for oxide systems $\mathrm{TiO}_{x}(\mathrm{a}, \mathrm{b})$ and $\mathrm{TiO}_{x} \cdot \mathrm{CoO}_{y}(\mathrm{c}$, d). Magnification $\times 200(\mathrm{a}, \mathrm{c})$ and $500(\mathrm{~b}, \mathrm{~d})$.

Table 1. Ti|TiO $\cdot \mathrm{CoO}_{y}$ system corrosion indices in the $0.1 \mathrm{M} \mathrm{NaCl}$ solution

\begin{tabular}{|c|c|c||}
\hline $\begin{array}{c}\text { Cobalt content } \\
\text { in the coating, } \\
\text { at. } \%\end{array}$ & $\begin{array}{c}\text { Corrosion } \\
\text { depth index } \\
\mathrm{k}_{\mathrm{h}} \cdot 10^{4}, \\
\mathrm{~mm} \cdot \mathrm{year}^{-1}\end{array}$ & $\begin{array}{c}\text { Corrosion } \\
\text { potential } E_{\text {cor }}, \\
\mathrm{V}\end{array}$ \\
\hline 0 & 2.33 & 0.05 \\
\hline 3 & 1.55 & 0.061 \\
\hline 5 & 1.16 & 0.094 \\
\hline 10 & 0.99 & 0.159 \\
\hline
\end{tabular}

$$
\begin{gathered}
2 \mathrm{Co}_{3} \mathrm{O}_{4} \rightarrow 6 \mathrm{CoO}+\mathrm{O}_{2}, \\
\Delta G_{298}^{0}=322.8 \mathrm{~kJ} .
\end{gathered}
$$

With the origination of sparking (section II) an increase in the voltage is considerably retarded (Fig. 1b) due to the breakdown of the barrier film $\mathrm{TiO}_{2}$. The titanium oxide formation rate is reduced and cobalt oxides $\mathrm{Co}_{3} \mathrm{O}_{4}$ are subjected to the thermal decomposition:

$$
\mathrm{CoO}_{2} \stackrel{-\mathrm{O}_{2}}{\longrightarrow} \mathrm{CO}_{2} \mathrm{O}_{3} \stackrel{-\mathrm{O}_{2}}{\longrightarrow} \mathrm{CO}_{3} \mathrm{O}_{4} .
$$

The transition to the region of microarcs (section III) is characterized by an insignificant change in the voltage and relative process stability (Fig. 1b), and PEO voltages are in the range of 120 to $160 \mathrm{~V}$. The sparking voltage shows the slope opposition to the cobalt concentration in the oxide coating (Fig. 1c), which is due to the increase in the content of cobalt in the oxide coating.

The data of microscopic studies of the morphology of oxide coatings are indicative of the formation of tubular surface $\mathrm{TiO}_{X}$ (Fig. 2a, b) and torus-like surface $\mathrm{TiO}_{x} \cdot \mathrm{CoO}_{y}$ with a rather lower porosity (Fig. 2c, d). Such a structure may provide the good substrate for the body cells deposition. In the case of artificial hip joint, the crucial parameter is a good sliding ability, which may be provided by the surface of a low roughness.

The distribution of main elements across the thickness of $\mathrm{TiO}_{x} \cdot \mathrm{CoO}_{y}$ coating (Fig. 3) proves the fact of inclusion of alloyed metals into the titanium oxide matrix, which can be achieved particularly in the PEO mode. A prevalence of titanium at the Tiloxide boundary and an increase in the concentration of phosphorus inclusions on the coating surface are quite natural.

A change in the behavior of diffraction patterns and also in the intensity of titanium oxide peaks and the origination of cobalt oxide peaks (Fig. 4) are indicative of the formation of mixed oxides $\mathrm{TiO}_{x} \cdot \mathrm{CoO}_{y}$ [27].

Impedance plots of mixed metal oxide systems with different cobalt content have 


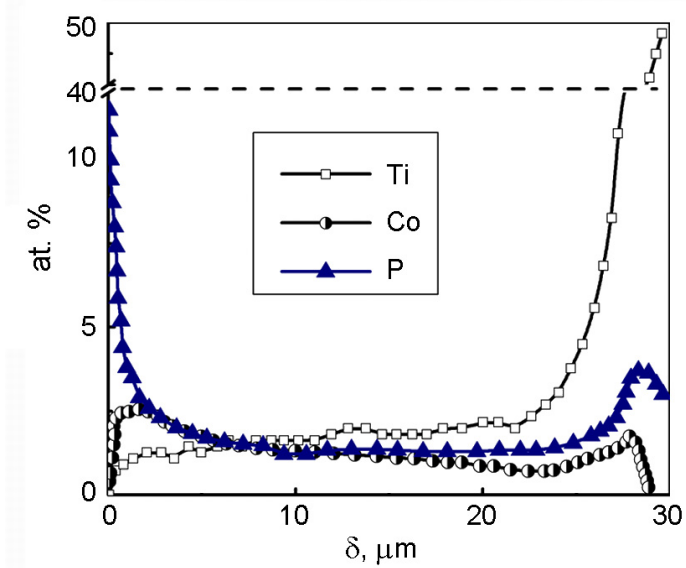

Fig. 3. Thickness distribution of the main components in the PEO-coating $\mathrm{TiO}_{x} \cdot \mathrm{CoO}_{y}$; The rest of at. $\%$ is oxygen. A level of $\delta=0$ corresponds to the coating surface.

the same shape. At high frequencies experimental points belong to semicircumference elements and at low frequencies the linear section appears with the slope angle of about $45^{\circ}$ that corresponds to the Warburg impedance (Fig. 5a). Such character of diagrams enables the description of metal oxide systems using the equivalent circuit (Fig. 5b) that contains the elements with the specific physical meaning: $R_{E}$ is the electrolyte resistance, Cd corresponds to the double electric layer capacitance at low frequencies and parametric resistance elements $R_{f}$ and $Z$ reflect the final rate of electrochemical reaction and that of the diffusion and their interdependence. The resistance $R_{f}$ is in inverse proportion to the current corrosion index, therefore it can be used for the determination of the corrosion resistance of materials [28].

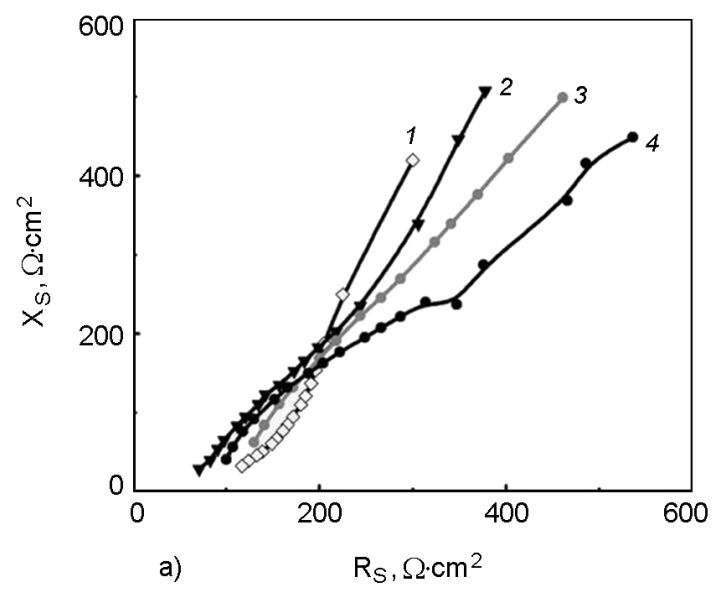

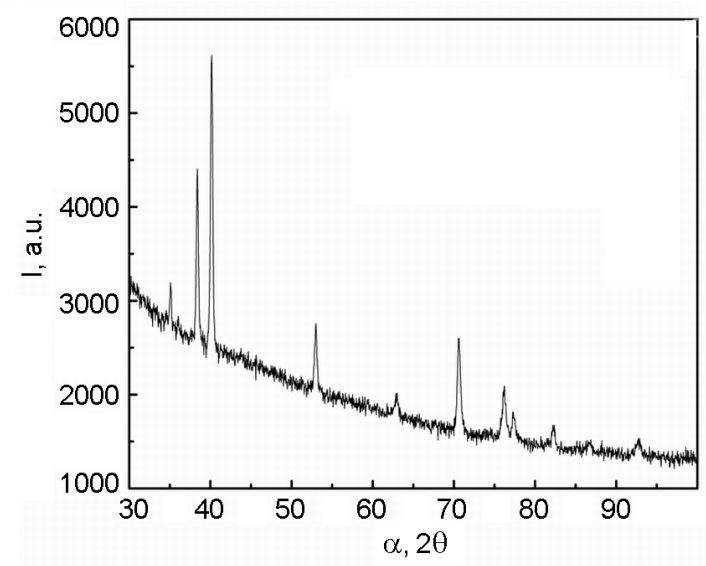

Fig. 4. Diffraction pattern of PEO coatings consisting of mixed oxides $\mathrm{TiO}_{x} \cdot \mathrm{CoO}_{y}$.

The corrosion depth index $k_{h}$ (Table 1) defined using $R_{f}$ showed that the corrosion resistance of $\mathrm{TiO}_{x} \cdot \mathrm{CoO}_{y}$ systems is increased with an increase in the content of cobalt in the coating.

The corrosion test data for $\mathrm{TiO}_{x} \cdot \mathrm{CoO}_{y}$ coatings in $2 \mathrm{M} \mathrm{NaOH}$ and Ringer's solutions (Table 2) are also indicative of high corrosion resistance.

In the case of $\mathrm{TiO}_{x} \cdot \mathrm{CoO}_{y}$ system, the highest anodic value of the corrosion potential may be associated with the close packed doughnut like grains filled with the small grains. The lowest corrosion resistance of coating $\mathrm{TiO}_{x}$ may be associated with the cracking of the formed layer, which promotes the penetration of electrolyte to the substrate.

The most significant is the resistance of mixed oxide systems $\mathrm{TiO}_{x} \cdot \mathrm{CoO}_{y}$ to the abrasive wear. The abrasive wear rate $\Delta l / \Delta t$ of the titania coating of composition, wt. $\%: 0$

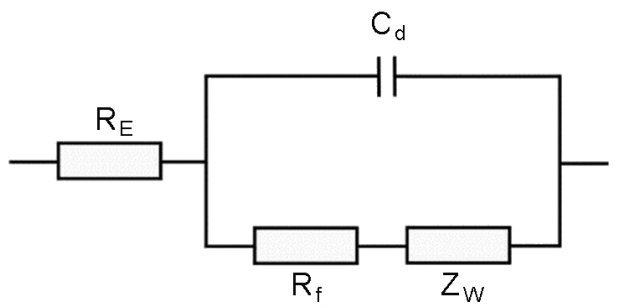

b)

Fig. 5. Impedance plots (a) and the equivalent circuit (b) of oxide coatings $\mathrm{TiO}_{x} \cdot \mathrm{CoO}_{y}$ with the cobalt content of at. $\%: 1-10 ; 2-5 ; 3-3 ; 4-0$. 
Table 2. Corrosion potentials of the specimens with the oxide coating $\mathrm{TiO}_{x} \cdot \mathrm{CoO}_{y}$

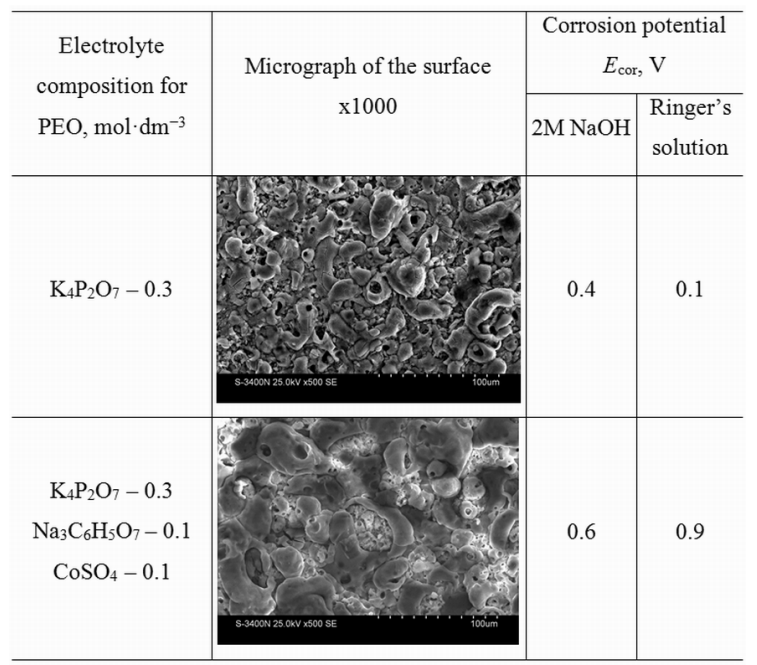

- 48.22; $\mathrm{Ti}-28.73 ; \mathrm{P}-16.25 ; \mathrm{K}-6.81$, and $30 \mu \mathrm{m}$ thickness is $1.05 \mu \cdot \mathrm{h}^{-1}$. Even at a coating thickness of $26 \mu \mathrm{m}$ a decrease in the diamantine bead abrasion rate for cobalt containing oxide system $(\mathrm{O}-58.22$; $\mathrm{Ti}-29.02$; Co - 2.11; $\mathrm{P}-7.95 ; \mathrm{K}-2.7)$ up to $0.75 \mu \cdot h^{-1}$ is observed. Such behavior may be explained due to the following reasons; in particular uniform distribution of cobalt over the coating thikness (see Fig. 3), globular-tubular structure and the spherical shape of grain agglomerates (Table 2).

Test data of the catalytic activity of coatings consisting of cobalt-based mixed oxides $\mathrm{TiO}_{x} \cdot \mathrm{CoO}_{y}$ with $\omega(\mathrm{Co})=5-7$ wt. \% that were tested using the model oxidation reaction of carbon oxide (II) show that the ignition temperature $T_{i}$ that corresponds to the start of the efficient work of catalyst is in the range of 250 to $270^{\circ} \mathrm{C}$ and it is somewhat higher than that of platinum contacts $\left(200^{\circ} \mathrm{C}\right)$. At $420^{\circ} \mathrm{C} \mathrm{TiO}_{x} \cdot \mathrm{CoO}_{y}$ coatings provide the $\mathrm{CO}$ conversion level of $68 \%$ (for Pt contacts - $100 \%$ ), and the full conversion is reached at higher temperatures. Such activity of oxide systems containing cobalt is quite acceptable for the creation on their basis of catalytic converters of toxicants of various natures.

\section{Conclusions}

Plasma electrolytic treatment of titanium alloys in citrate-diphosphate electrolytes at a voltage of 120 to $160 \mathrm{~V}$ enables the formation of mixed metal oxide systems with the cobalt content of 5 to 10 at. $\%$. It is shown that the availability of inverse relation of the sparking voltage as a function of the dopant concentration in the electrolyte is conditioned by an increase in the electric conductivity of mixed oxides that gain thickness due to a higher conductivity of oxide dopant compounds.

$\mathrm{TiO}_{x} \cdot \mathrm{CoO}_{y}$ coatings have a microporous globular torus-like surface without cracks that provides both substantial corrosion and high abrasive wear resistance.

Mixed oxide coatings are characterized by the developed surface and high catalytic activity in the carbon (II) oxide conversion reaction. This confirms the efficiency of materials as catalysts for the gaseous waste neutralization and the processes of hydrocarbon combustion.

\section{References}

1. S.Bagheri, N.Muhd Julkapli, S.Bee Abd Hamid, The Sci. World J., 58, 635 (2014).

2. C.Veiga, J.P.Davim, A.J.R.Loureiro, Rev.Adv. Mater., 32, 2 (2012).

3. M.Anpo, P.V.Kamat, Environmentally Benign Photocatalysts: Applications of Titanium Oxide-based Materials, Springer Science, New York (2010).

4. Z.R.Ismagilov, L.T.Tsikoza, N.V.Shikina et al., Rus. Chem. Rev., 78, 9 (2009).

5. C.Oldani, A.Dominguez, Recent Advances in Arthroplasty, InTech (2012).

6. C.N.Elias, J.H.C.Lima, R.Valiev, M.A.Meyers, JOM, 60, 3 (2008).

7. M.J.Jackson, W.Ahmed, Surface Engineered Surgical Tools and Medical Devices, Springer, New York (2007).

8. M.T.Mohammed, Z.A.Khan. A.N.Siddiquee, Proc. Mater. Sci., 6, 1610 (2014).

9. A.Kazek-Kesika, M.Krok-Borkowicz, G.Dercz et al., Electrochim.Acta, 204, 294 (2016).

10. N.Masuko, T.Osaka, Y.Ito, Electrochemical Technology: Innovation and New Technologies, Kodansha, Gordon and Breach (1996).

11. I.V.Lukiyanchuk, V.S.Rudnev, L.M.Tyrina, Surf. Coat.Technol., 307, 1183 (2016).

12. G.Yar-Mukhamedova, M.Ved, N.Sakhnenko et al., Appl.Surf. Sci., 383, 346 (2016).

13. N.D.Sakhnenko, M.V.Ved', D.S.Androshchuk, S.A.Korniy, Surf.Eng.Appl.Elect., 52, 145 (2016).

14. M.S.Vasilyeva, V.S.Rudnev, A.Yu.Ustinov et al., Appl.Surf. Sci., 257, 1239 (2010).

15. N.Sakhnenko, O.Ovcharenko, M.Ved, Functional Materials, 22, 105 (2015.)

16. P.Gupta, G.Tenhundfeld, E.O.Daigle, D.Ryabkov, Surf. Coat. Technol., 201, 8746 (2007).

17. V.V.Bykanova, N.D.Sakhnenko, M.V.Ved', Surf.Eng.Appl.Elect., 51, 276 (2015).

18. N.D.Sakhnenko, M.V.Ved', A.V.Karakurkchi, A.V.Galak, East.-Europ.J. Enterp. Technol., 3, 37 (2016).

19. Z.ur Rahman, I.Shabib, W.Haider, Mater.Sci. Engin., 67, 675 (2016). 
20. E.Krasicka-Cydzik, Corros Sci., 46, 2487 (2004).

21. B.Yang, M.Uchida, H.-M.Kim et al., Biomater., 25, 1003 (2004).

22. M.Glushkova, T.Bairachna, M.Ved, M.Sakhnenko, MRS Proceed., 1491 (2013).

23. I.V.Lukiyanchuk, I.V.Chernykh, V.S.Rudnev et al., Prot.Met.Phys.Chem.Surf., 50, 209 (2014).

24. M.V.Ved', N.D.Sakhnenko, O.V.Bogoyavlenska, T.O.Nenastina, Mater. Sci., 44, 79 (2008).
25. A.Kassman, S.Jacobson, L.Ericson et al., Surf. Coat. Techn., 50, 75 (1991).

26. P.V.Snytnikov, V.D.Belyaev, V.A. Sobyanin, Kinet.Catal., 48, 93 (2007).

27. M.V.Ved', A.V.Karakurkchi, N.D.Sakhnenko, A.S.Gorohivskiy, Chem.Phys.Technol.Surf., 8, 73 (2017).

28. N.D.Sakhnenko, M.V.Ved, Yu.V.Vestfrid, I.I.Stepanova, Zh. Prikladnoi Khimii, 69, 1346 (1996).

29. P.V.Snytnikov, V.D.Belyaev, V.A.Sobyanin, Kinet.Catal., 48, 93 (2007). 